\title{
WHY PAKISTAN'S ECONOMIC GROWTH CONTINUES TO BE BALANCE-OF-PAYMENTS CONSTRAINED
}

Kristian Rosbach and Lilia Aleksanyan

\section{NO. 8}

\section{ADB CENTRAL AND WEST ASIA WORKING PAPER SERIES}



ADB Central and West Asia Working Paper Series

\section{Why Pakistan's Economic Growth Continues to Be Balance-of-Payments Constrained}

Kristian Rosbach and Lilia Aleksanyan

No. 8 | December 2019
Kristian Rosbach and Lilia Aleksanyan are economists at the

Central and West Asia Department, Asian Development Bank. 
(C) 2019 Asian Development Bank 6 ADB Avenue, Mandaluyong City, 1550 Metro Manila, Philippines

Tel +63 28632 4444; Fax +63286362444

www.adb.org

Some rights reserved. Published in 2019.

Printed in the Philippines.

Publication Stock No. WPS190599-2

DOI: http://dx.doi.org/10.22617/WPS190599-2

The views expressed in this publication are those of the authors and do not necessarily reflect the views and policies of the Asian Development Bank (ADB) or its Board of Governors or the governments they represent.

ADB does not guarantee the accuracy of the data included in this publication and accepts no responsibility for any consequence of their use. The mention of specific companies or products of manufacturers does not imply that they are endorsed or recommended by ADB in preference to others of a similar nature that are not mentioned.

By making any designation of or reference to a particular territory or geographic area, or by using the term "country" in this document, $A D B$ does not intend to make any judgments as to the legal or other status of any territory or area.

This work is available under the Creative Commons Attribution 3.0 IGO license (CC BY 3.0 IGO) https://creativecommons.org/licenses/by/3.0/igo/. By using the content of this publication, you agree to be bound by the terms of this license. For attribution, translations, adaptations, and permissions, please read the provisions and terms of use at https://www.adb.org/terms-use\#openaccess.

This CC license does not apply to non-ADB copyright materials in this publication. If the material is attributed to another source, please contact the copyright owner or publisher of that source for permission to reproduce it. ADB cannot be held liable for any claims that arise as a result of your use of the material.

Please contact pubsmarketing@adb.org if you have questions or comments with respect to content, or if you wish to obtain copyright permission for your intended use that does not fall within these terms, or for permission to use the ADB logo.

Corrigenda to ADB publications may be found at http://www.adb.org/publications/corrigenda.

Notes:

In this report, "\$" refers to United States dollars.

ADB recognizes "China" as the People's Republic of China.

The ADB Central and West Asia Department (CWRD) Working Paper Series is a forum for stimulating discussion and eliciting feedback on ongoing and recently completed economic, sector, and policy work undertaken by ADB staff members, consultants, or resource persons in the context of the operational work of CWRD. The series deals with economic and development issues in Central and West Asia, and aims to improve the knowledge of Central and West Asia's development and policy challenges, strengthen subregional and country operations, and contribute to national and regional policy dialogue.

The series is a quick-disseminating, informal publication. The working papers may subsequently be revised and published elsewhere. 


\section{CONTENTS}

TABLES AND FIGURES

iv

ACKNOWLEDGMENTS

v

ABSTRACT

vi

ABBREVIATIONS

vii

I. INTRODUCTION

II. FROM CURRENT ACCOUNT IMBALANCES TO BALANCE-OF-PAYMENTS CONSTRAINTS

III. MEASURING PAKISTAN'S BALANCE-OF-PAYMENTS CONSTRAINT

TO ECONOMIC GROWTH

A. Balance-of-Payments Constrained Growth Model: Simple Representation 4

B. Imports Demand Function for Pakistan 5

C. Exports Demand Function for Pakistan 6

D. Balance-of-Payments Constrained Economic Growth Rate $\quad 7$

$\begin{array}{ll}\text { IV. POLICY RECOMMENDATIONS } & 9\end{array}$

V. CONCLUSIONS

APPENDIXES

1. Pesaran, Shin, and Smith (2001) Bounds Test

2. Diagnostic Tests for Import and Export Demand Equations 


\section{TABLES AND FIGURES}

\section{Tables}

$1 \quad \operatorname{ARDL}(1,1,0)$ Model of Imports Demand: Error Correction Model 6

2 ARDL $(2,6,0)$ Model of Exports Demand: Error Correction Model 7

3 Calculation of Balance-of-Payments Equilibrium Growth Rate, 1980-2017 8

A1.1 ARDL $(1,1,0)$ Model for Imports Demand Equation 12

A1.2 ARDL $(1,5,0)$ Model for Exports Demand Equation 12

A2.1 Imports Demand Regression Model ARDL (1,1,0): Breusch-Pagan/Cook-Weisberg Test for Heteroskedasticity

A2.2 Imports Demand Regression Model ARDL (1,1,0): Breusch-Godfrey LM Test for Autocorrelation

A2.3 Imports Demand Regression Model ARDL (1,1,0): Cumulative Sum Test for Parameter Stability

A2.4 Imports Demand Regression Model ARDL (1,1,0): Wald Test for a Structural Break (Structural Break in 2001)

A2.5 Cumulative Sum Test for Parameter Stability

A2.6 Exports Demand Regression Model ARDL (2,6,0): Breusch-Pagan/Cook-Weisberg Test for Heteroskedasticity

A2.7 Exports Demand Regression Model ARDL (2,6,0): Breusch-Godfrey Lagrange Multiplier Test for Autocorrelation

A2.8 Augmented Dickey-Fuller Test for Unit Root

\section{Figures}

1 Import Growth versus Gross Domestic Product Growth, 1997-2017

2 Economic Growth Rate and Balance-of-Payments Constraint, 1980-2017 


\section{ACKNOWLEDGMENTS}

The authors thank Carmela Espina, Safdar Parvez, Jesus Felipe, Xiaohong Yang, Joao Pedro Farinha, Irfan A. Qureshi, the ADB Pakistan Resident Mission, and participants in the ADB Economic Research and Regional Cooperation Department seminar (13 February 2019) for their valuable comments and suggestions. 


\begin{abstract}
This paper aims to analyze Pakistan's recurring balance-of-payments crisis. Based on 1980-2017 data and using long-term estimates of import and export income elasticities, the authors estimate the balance-of-payments constrained growth rate at 3.8\%. The result is lower than previous estimates of balance-of-payment constrained growth in the literature, indicating that lower export performance weighed more on GDP growth in the recent period. This paper calls for structural reforms to improve Pakistan's export performance.

Keywords: Pakistan, balance-of-payments, GDP growth, import elasticity, export elasticity

JEL classification: O110, O190, E650
\end{abstract}




\section{ABBREVIATIONS}

ARDL autoregressive distributed lag

BOP balance-of-payments

FY fiscal year

GDP gross domestic product

IMF International Monetary Fund

MIT Massachusetts Institute of Technology

REER real effective exchange rate

SBP State Bank of Pakistan 



\section{INTRODUCTION}

Since the 1980s, a pattern of recurring spurts of high economic growth followed by episodes of economic crisis has held back Pakistan's sustained economic development. Economic reform programs, partly assisted by international development partners, have not resulted in sustainably breaking reoccurring boom and bust cycles. This paper discusses Pakistan's long-term economic growth performance in 1980-2017.

Thirlwall's balance-of-payments (BOP)-constrained growth model ${ }^{1}$ and the methodological framework developed in Felipe et al. ${ }^{2}$ calculates Pakistan's maximum growth rate, consistent with equilibrium on the basic balance, at approximately 5\% per annum. The BOP-constrained growth model helps explain why periods of higher economic growth resulted in a depletion of foreign currency reserves. In the past, macroeconomic measures to reverse foreign reserve outflows often resulted in slowing economic growth.

This paper argues that Pakistan's gross domestic product (GDP) rate is BOP-constrained. Using Thirlwall's model ${ }^{3}$, a hypothetical long-term BOP equilibrium GDP growth rate of $3.8 \%$ is calculated. This suggests that, in the current structural and product specialization circumstances, if Pakistan's economy is to grow faster than 3.8\% in the medium-term, external imbalances will occur. This is consistent with Pakistan's reoccurring BOP crisis since the 1980s and the resulting foreign exchange reserve shortages.

\section{FROM CURRENT ACCOUNT IMBALANCES TO BALANCE-OF-PAYMENTS CONSTRAINTS}

Pakistan's economy is semi-industrialized, relying heavily on textiles, agriculture, and food production. With industry contributing on average $21 \%$ to GDP, with a declining share since 2015 , the economy is increasingly dominated by the services sector, which contributes $51 \%$ to GDP while agriculture contributes around $23 \%$. The employment shares for agriculture, industry, and services, on average, over the last two decades are $43 \%, 21 \%$, and $36 \%$, respectively.

In the 1980s, following deregulation policies, increased inflow of foreign aid and remittances from expatriate workers, Pakistan's economy experienced high economic growth rates, averaging 6.9\% annually. In the 1990s, economic growth averaged 4.0\%. During this period, Pakistan experienced a debt crisis, which was triggered by persistent fiscal and external deficits. Exports stagnated and Pakistan lost market share in a buoyant world trade environment. Poverty increased from 57.9\% in 1998 to a high of $64.3 \%$ in $2001 .{ }^{4}$ However, by 2010 , poverty had reduced to $36.8 \%$ following sustained average economic growth rates of $4 \%-5 \%$. During 2010-2017, average economic growth decreased to $4.1 \%$, with poverty further shrinking to $24.3 \%$. Pakistan's economic growth tends to be pro-poor in the sense that the growth elasticity of poverty reduction is relatively high. ${ }^{5}$

1 Thirlwall, A. P. 1979. The balance of payments constraint as an explanation of international growth rate differences. In Banca Nazionale del Lavoro Quarterly Review, 128, pp. 45-53. Rome.

2 Felipe, J., McCombie, J.S.L.; and Naqvi, K. 2010. Is Pakistan's Growth Rate Balance-of-Payments constrained? Policies and Implications for Development and Growth. Oxford Development Studies. 38 (4). pp. 477-496. Oxford.

3 Footnote 1.

4 Poverty headcount ratio at national poverty lines (\% of population). National estimates are based on population-weighted subgroup estimates from household surveys.

5 World Bank. 2013. The Transformative Path. Washington, D.C. 


\section{Figure 1: Import Growth versus Gross Domestic Product Growth, 1997-2017} (\%)

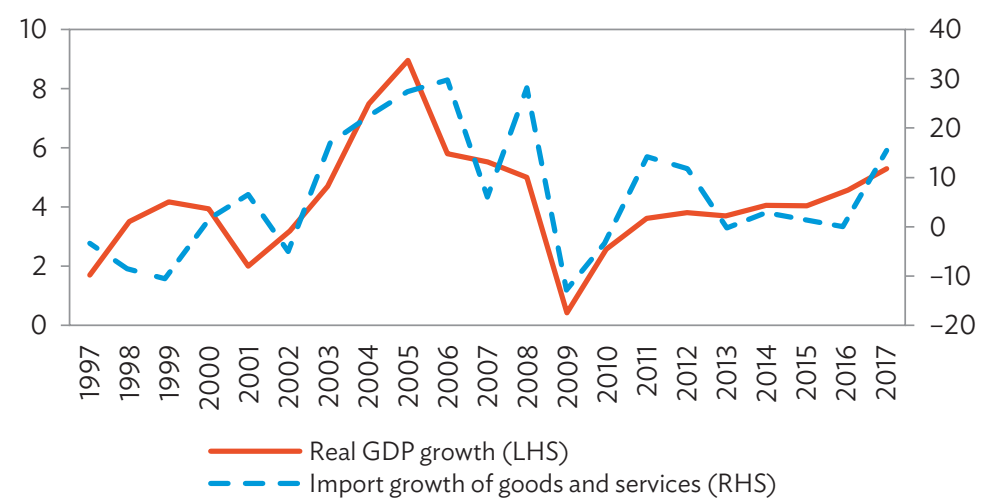

GDP = gross domestic product, $\mathrm{LHS}=$ left-hand side, $\mathrm{RHS}=$ right-hand side.

Note: The data in this graph are based on fiscal years.

Sources: The World Bank; State Bank of Pakistan.

In the past, Pakistan's episodes of high economic growth were usually marked by disproportionally higher import growth (Figure 1). This was due to several factors. First, energy imports largely contributed to a surge in overall imports. Pakistan had insufficient energy supplies and an energy mix that relied on imported furnace oil and natural gas. ${ }^{6}$ Imported furnace oil was often used to run smaller generators during blackouts and brownouts in urban areas and by manufacturers in times of high economic growth to keep up with demand. 'Second, since Pakistan did not produce machinery that was crucial for manufacturing and infrastructure development, it continued its reliance on imports. Third, past investments did not improve the productive capabilities of the country to enable it to substitute some of imports and shift its pattern of specialization towards more sophisticated products. ${ }^{8}$

Pakistan's export performance has been weak for decades. Since 2010, export growth has been largely stagnant, with a growing average trade deficit. Pakistan's exports continue to lose market shares due to the growing proportion of unsophisticated export goods. These are generally characterized by low income elasticity of demand and high price elasticity of demand. Thus, Pakistan's exports have not kept pace with global income growth. According to the Massachusetts Institute of Technology (MIT) Observatory of Economic Complexity, ${ }^{9}$ Pakistan ranks 74th out of 89 countries in the economic complexity ranking. The World Bank has also given Pakistan one of the lowest rankings in the world for the share of exports

6 "The power sector's inability to recover its full costs over long time-periods have created a circular debt situation wherein the sector's financial problems have spilled over to other sectors in the supply chain, including fuel and equipment suppliers. Limited action in addressing the underlying causes of the circular debt has kept investments at less than desired levels until 2017; generation has remained below load requirements, and losses in the transmission and distribution systems have remained high." See ADB. 2018. Evaluation Approach: Sector Assistance Program Evaluation (SAPE) for the Pakistan Power Sector. Manila.

7 Alam, M. 2013. Coping with Blackouts: Power Outages and Firm Choices. Working Paper, Yale University. Yale.

8 The Economist. 2017. Pakistan's Misguided Obsession with Infrastructure. 19 January. https://www.economist.com/ asia/2017/01/19/pakistans-misguided-obsession-with-infrastructure (accessed 5 July 2019).

9 MIT Media Lab, Observatory of Economic Complexity. https://atlas.media.mit.edu/ (accessed 17 August 2018). 
in GDP, at only $8.2 \%$ in $2017 . .^{10}$ The country's exports are mainly concentrated in garments and animal products. More sophisticated export products with higher domestic value added represent only a small share of total exports.

Pakistan's dominant export category is textiles, which accounts for $58 \%$ of all its exports in 2017. Between 2012 and 2017, Pakistan's export industries were affected by an overvalued exchange rate, which reduced its price competitiveness. In addition, exporters experienced high costs as a result of energy prices and insufficient energy supplies.

Limited non-price competitiveness of merchandise exports contributes to constrained economic growth in the long-run. ${ }^{11,12,13}$ Pakistan's exports are relatively unsophisticated, which, to a significant extent, implies that they are rather unresponsive to global economic growth (i.e., their export income elasticity of demand is relatively low). ${ }^{14}$ Increases in domestic demand in Pakistan has tended toward relatively large increases in imports, particularly for imported petroleum products, a result of the country's energy mix. 15,16 Thus, gaps in Pakistan's trade balance are structural, emerging whenever domestic demand grows too fast. This implies that solutions have to be of a structural nature and target a particular result. Raising Pakistan's economic growth rate in a way that remains consistent with BOP equilibrium would require reforms that would help its industries produce export products that are more attractive to external markets, as well as reducing the income elasticity of imports. This means that the country's import-competing industries should become more competitive, and the energy mix should be altered to become less reliant on oil imports.

In the past, remittances have cushioned the financing pressures related to Pakistan's trade deficit. According to BOP data from the International Monetary Fund (IMF), in the 1980s, remittances financed, on average, $32.4 \%$ of imports, dropping to $12.9 \%$ in the 1990s. Between 2000 and 2017, the share recovered to an average $17.8 \%$ and peaked at 31.3\%. With high oil prices in 2005-2008 and 2010-2014, remittances became more concentrated from Middle Eastern oil-exporting countries. However, since the oil price drop in 2014, remittances can no longer compensate for the growing trade deficit. ${ }^{17}$ Given the importance of remittances for the BOP, it has been included in the BOP-constrained growth model.

10 The World Bank. Exports of Goods and Services (\% of GDP). https://data.worldbank.org/indicator/NE.EXP.GNFS.ZS?end $=2017 \&$ start $=2016 \&$ year_low_desc=fals (accessed 3 September 2018).

11 Iqbal, Z. and Rehman, Q.N. 1995. Constraints to the Economic Growth of Pakistan: A Three-Gap Approach. The Pakistan Development Review. 34 (4). pp. 1119-1133. Islamabad.

12 Fida, B.A., Zakaria, M., Hashmi, S.M. 2009. Balance of Payments Constrained Growth Model: A Case Study of Pakistan. European Journal of Scientific Research. 25 (4). pp. 574-583. Mahé.

13 Mirza, F.M. and Mazhar, U. 2012. Is Pakistan's Economic Growth Balance of Payments Constrained?. Journal of Asian Development Studies. 1 (4). pp. 44-54. Gujarat.

14 See Table 2. A 1.0\% change in weighted GDP growth of Pakistan's trading partners results in a $1.04 \%$ change in demand for Pakistan's exports. For comparison, also see: Baluch, K.A. and Bukhari, S.K.H. 2012. Price and Income Elasticity of Imports: The Case of Pakistan. State Bank of Pakistan Working Paper Series. No. 48. Karachi.

15 While petroleum products' share of Pakistan's imports was at 24\% in 2006 and 2007, it jumped to 32\% in 2008, before the effects of the global financial crisis on the country's petroleum imports became manifest. With the 2008 financial crisis, the slow economic growth that year (1.9\%) and in 2009 (0.4\%), and the oil price drop, the share of petroleum-product imports dropped to $26 \%$ in 2009 . It rose to $28 \%$ in 2010 , however, and after that climbed well above the previous levels, reaching $32 \%$ in 2011, and 35\% in 2012 and 2013.

16 The elasticity value for imported fuel is 1.44 (significant). See Ahmed, Ch.S. 2011. Aggregate Imports and Expenditure Components in Pakistan: An Empirical Analysis. Pakistan Business Review. 3. pp. 488-512. Karachi.

17 Exports used to finance an increasing share of imports between the 1980s (54.7\%), the 1990s (71.9\%), and the 2000s (73.9\%), which, however, sharply declined to 59.6\% between 2010 and 2017. 


\section{MEASURING PAKISTAN'S BALANCE-OF-PAYMENTS CONSTRAINT TO ECONOMIC GROWTH}

A country's economic growth is considered BOP-constrained if its average economic growth rate is above the rate that is in line with a long-run BOP equilibrium, and does not lead to a structural net foreign exchange outflow. The paper of Felipe et al. (2010) ${ }^{18}$ estimated Pakistan's long-term economic growth with its BOP constraint and found it to be lower than the country's average growth for 1980-2007. The 2010 paper found that Pakistan's high growth rates between 2004 and 2007 led to a foreign exchange reserve crisis. The rest of this section presents a BOP-constrained growth model for Pakistan, the empirical strategy to measure the BOP-constrained growth level, and estimation results.

\section{A. Balance-of-Payments Constrained Growth Model: Simple Representation}

The test to assess whether Pakistan's growth rate is BOP-constrained is based on the approach promulgated by Thirlwall. ${ }^{19}$ The hypothetical BOP equilibrium growth can be calculated as follows:

$$
y_{B P}=\frac{x}{\pi}
$$

where $x$ is the growth rate of exports and $\pi$ is the income elasticity of demand for imports.

This paper closely follows the estimation approach of Felipe et al. (2010), who used an augmented balance-of-payments equilibrium growth rate expression, including remittances, as an important source of foreign exchange, and the effect of terms of trade:

$$
y_{B P}^{\text {augmented }}=\frac{\theta_{x} \varepsilon z+\theta_{R}\left(r-p_{X}\right)+\left(p_{X}-p_{M}\right)}{\pi}
$$

where $\theta_{x}$ is the share of exports in foreign currency receipts; $\theta_{R}$ is the share of remittances in foreign currency receipts; $\varepsilon$ is the country's trading partners' income elasticity of demand for the country's exports; $z$ is the country's trading partners' incomes, each weighted by its export share; $r$ is growth of real remittances; and $\left(p_{X}-p_{M}\right)$ is growth of terms of trade. ${ }^{20}$

Imports generally take time to adjust to changes in a country's income or relative prices. Therefore, it is important to take into account the short- and long-term income and price elasticities of import demand as they tend to increase with time.

The import demand function is a function of real effective exchange rate (REER) and the income variable-defined as domestic GDP. The theoretical relationship is that the demand for imports is negatively related to the relative price of imports and positively related to economic activity-or aggregate demand. This specification is a traditional and successful approach in the literature. Similarly, the export demand function is a function of REER and the income variable, defined as the GDP of country's trading partners.

\footnotetext{
18 Footnote 2.

19 Footnote 1.

20 This equation corresponds to the equation (9) of Felipe et al. (footnote 2), although their empirical estimation is based on equation (8) of their paper, which uses the equation (9) but includes an additional term to account for other capital inflows. This paper assumes that there are no other capital flows than remittances.
} 


\section{B. Imports Demand Function for Pakistan}

The longrun effects of GDP growth on imports is investigated using the traditional Autoregressive Distributed Lag Model (ARDL) approach. Pesaran and Smith (1995) ${ }^{21}$ and Pesaran and Shin (1999) ${ }^{22}$ show that the ARDL approach can be used for long-run analysis. Moreover, the ARDL methodology is valid for stationary $(I(0)$ ) or integrated-order $1(I(1))$ variables. To illustrate the ARDL modeling approach, the simple model of import demand function ${ }^{23}$ can be considered. Import demand can be calculated as follows:

$$
\text { Imports }_{t}=\alpha+\beta G D P_{t}+\delta R E E R_{t}+e_{t}
$$

where $e_{t}$ is the error term at time t.

The error correction version of the ARDL model is given by:

$$
\begin{aligned}
\text { Imports }_{t}= & \alpha_{0}+\sum_{i=1}^{p} \beta_{i} \Delta \text { Imports }_{t-1}+\sum_{i=1}^{p} \delta_{i} \Delta G D P_{t-1}+\sum_{i=1}^{p} \varepsilon_{i} \Delta \text { REER }_{t-1} \\
& +\lambda_{1} \text { Imports }_{t-1}+\lambda_{2} G D P_{t-1}+\lambda_{3} \text { REER }_{t-1}+u_{t}
\end{aligned}
$$

where $u_{t}$ is the error term.

The first part of the equation, with $\beta, \delta$, $\varepsilon$, represents short-run dynamics of the model. The second part, with $\lambda$ s, represents the long-run relationship. The null hypothesis in the equation that is tested below is $\lambda_{1}=\lambda_{2}=\lambda_{3}=0$, which means the nonexistence of a long-run relationship.

First, the stationarity of the imports, GDP, and REER series, is examined based on the augmented DickeyFuller test. The test suggests that domestic GDP and imports are non-stationary in levels but stationary in first difference. The REER variable is an exception as it is stationary in levels and in first difference. However, the advantage of the ARDL approach is that it does not require stationarity tests of individual regressors. Regardless of whether the variables are integrated of order zero or one, the ARDL approach allows us to obtain consistent estimates.

To establish whether a long-run relationship exists among the variables, a bound test was performed. Appendix 1 provides F-test statistic to test for the presence of a long-run relationship between the imports, GDP, and REER. As the value of F-test lies outside the band of the critical values at $10 \%$ significative level, conclusive inference about the existence of a long-run level relationship between imports, GDP, and REER can be made without taking into account the order of integration of the regressors.

Table 1 reports the long-run coefficients of the estimation of equation 4 by the ARDL method. From these results, it can be concluded that the income elasticity of import with respect to Pakistan's GDP is estimated as 0.8 . A $1.0 \%$ change in GDP will result in a long-run change of about $0.8 \%$ in imports.

\footnotetext{
21 Pesaran, M. and Smith, R. 1995. Estimating long-run relationships from dynamic heterogeneous panels. Journal of Econometrics, Volume 68, Issue 1, pp. 79-113. Amsterdam.

22 Pesaran, M. and Shin, Y. 1999. Autoregressive Distributed Lag Modeling Approach to Cointegration Analysis. Centennial Volume of Rognar Frisch, eds. S. Strom, A. Holly and P. Diamond, Cambridge University Press. Cambridge.

${ }^{23}$ Our simple model of import demand includes two underlying regressors of GDP and REER. A proxy for relative price has not been included, following the assumptions discussed in Felipe et al. (footnote 2). The existence of exchange rate pass-through is assumed to aggregate import prices in short-run and long-run. Thus, REER is considered as a proxy for imports prices.
} 
Table 1: ARDL $(1,1,0)$ Model of Imports Demand: Error Correction Model

\begin{tabular}{|c|c|c|c|c|c|c|}
\hline \multicolumn{7}{|c|}{ Dependent Variable: $\Delta$ Log(Imports) } \\
\hline & & Standard & & & \multirow{2}{*}{\multicolumn{2}{|c|}{ [95\% Confidence Interval] }} \\
\hline & Coefficient & Error & $\mathrm{t}$-Value & $P>t$ & & \\
\hline \multicolumn{7}{|c|}{ Speed of adjustment coefficient } \\
\hline $\log (\operatorname{Imports})_{\mathrm{t}-1}$ & -0.553 & 0.154 & -3.590 & 0.001 & -0.867 & -0.239 \\
\hline \multicolumn{7}{|c|}{ Long-run coefficients (Newey-West standard errors) } \\
\hline $\log (G D P)$ & 0.797 & 0.110 & 7.250 & 0.000 & 0.582 & 1.013 \\
\hline $\log (R E E R)$ & 0.127 & 0.223 & 0.570 & 0.569 & -0.311 & 0.565 \\
\hline \multicolumn{7}{|c|}{ Short-run coefficients } \\
\hline$\Delta \log (G D P)$ & 0.668 & 1.090 & 0.610 & 0.544 & -1.552 & 2.888 \\
\hline Constant & 1.646 & 1.997 & 0.820 & 0.416 & -2.422 & 5.714 \\
\hline
\end{tabular}

Sample: 1980-2017

Number of observations: 37

R-squared: 0.3807

$\mathrm{GDP}=$ gross domestic product, $\mathrm{REER}$ = real effective exchange rate.

As expected, the error correction term, represented as speed of adjustment coefficient, is negative, with an associated coefficient estimate of -0.553 . This implies that more than $55 \%$ of any movements into disequilibrium are corrected within one period. The coefficient of this term is highly significant and shows a relatively high speed of adjustment.

\section{Exports Demand Function for Pakistan}

The long-run effects of GDP growth on exports are investigated using the ARDL approach, as for the imports demand function. The simple model of export demand function can be considered as follows:

$$
\text { Exports }_{t}=\alpha+\beta Z_{t}+\delta R E E R_{t}+e_{t}
$$

where $Z$ is the GDP of Pakistan's main trading partners weighted by their individual exports' share.

The error correction version of the ARDL model is given by:

$$
\begin{aligned}
\Delta \text { Exports }_{t}= & \alpha_{0}+\sum_{i=1}^{p} \beta_{i} \Delta \text { Exports }_{t-1}+\sum_{i=1}^{p} \delta_{i} \Delta Z_{t-1}+\sum_{i=1}^{p} \varepsilon_{i} \Delta R E E R_{t-1} \\
& +\lambda_{1} \text { Exports }_{t-1}+\lambda_{2} Z_{t-1}+\lambda_{3} \text { REER }_{t-1}+u_{t}
\end{aligned}
$$

The first part of the equation, with $\beta, \delta$, $\varepsilon$, represents short-run dynamics of the model. The second part, with $\lambda$ s, represents the long-run relationship. The null hypothesis in the equation that is tested below is $\lambda_{1}=\lambda_{2}=\lambda_{3}=0$, which means nonexistence of a long-run relationship. To establish whether a long-run relationship exists among the variables, a bound test was performed (see Appendix 1). The F-test value lies outside the band of the critical values at 10\% significance level, indicating the existence of a lonrun level relationship between exports, GDP of trading partners, and REER. 
Table 2: ARDL $(2,6,0)$ Model of Exports Demand: Error Correction Model

\begin{tabular}{|c|c|c|c|c|c|c|}
\hline \multicolumn{7}{|c|}{ Dependent Variable: $\Delta$ Log(Exports) } \\
\hline & & Standard & & & \multirow{2}{*}{\multicolumn{2}{|c|}{ [95\% Confidence Interval] }} \\
\hline & Coefficient & Error & $\mathrm{t}$-value & $P>t$ & & \\
\hline \multicolumn{7}{|l|}{ Speed of adjustment coefficient } \\
\hline $\log (\text { Exports })_{t-1}$ & -0.636 & 0.192 & -3.320 & 0.003 & -1.035 & -0.237 \\
\hline \multicolumn{7}{|c|}{ Long-run coefficients (Newey-West standard errors) } \\
\hline Log(GDP of trading partners) & 1.042 & 0.098 & 10.640 & 0.000 & 0.850 & 1.234 \\
\hline $\log (\mathrm{REER})$ & 0.912 & 0.304 & 3.000 & 0.003 & 0.315 & 1.509 \\
\hline \multicolumn{7}{|l|}{ Short-run coefficients } \\
\hline$\Delta \log ($ Exports) & 0.132 & 0.181 & 0.730 & 0.474 & -0.244 & 0.507 \\
\hline$\Delta \log (G D P$ of trading partners) & -1.100 & 0.413 & -2.660 & 0.015 & -1.960 & -0.240 \\
\hline$\Delta \log (G D P \text { of trading partners })_{\mathrm{t}-1}$ & -0.734 & 0.415 & -1.770 & 0.091 & -1.598 & 0.129 \\
\hline$\Delta \log (G D P \text { of trading partners })_{t-2}$ & -0.909 & 0.428 & -2.120 & 0.046 & -1.800 & -0.019 \\
\hline$\Delta \log (G D P \text { of trading partners })_{t-3}$ & -0.724 & 0.295 & -2.450 & 0.023 & -1.338 & -0.111 \\
\hline$\Delta \log (G D P \text { of trading partners })_{t-4}$ & -0.568 & 0.283 & -2.010 & 0.058 & -1.156 & 0.021 \\
\hline$\Delta \log (G D P \text { of trading partners })_{t-5}$ & -0.241 & 0.257 & -0.940 & 0.359 & -0.776 & 0.294 \\
\hline Constant & -6.748 & 5.314 & -1.270 & 0.218 & -17.798 & 4.302 \\
\hline $\begin{array}{l}\text { ARDL }(2,6,0) \text { regression } \\
\text { Sample: } 1980-2017 \\
\text { Number of observations: } 32 \\
\text { R-squared: } 0.4952\end{array}$ & & & & & & \\
\hline
\end{tabular}

$\mathrm{GDP}=$ gross domestic product, $\mathrm{REER}=$ real effective exchange ate .

Table 2 reports the long-run coefficients of the estimation of ARDL $(1,5,0)$ equation for the model Eq. 6. From these results, it can be concluded that the income elasticity of export with respect to Pakistan's trading partners' GDP is estimated as 1.04 . Hence, a 1.0\% change in GDP of main trading partners will result in a long-run change in exports of $1.04 \%$. The coefficient of REER to exports is positive, contrary to what was expected. Although this paper does not focus on exploring the relationship between the exchange rate and exports, the initial intuition indicates that the positive coefficient reflects the nature of Pakistan's exports.

The speed of adjustment coefficient is negative and it is statistically significant. The coefficient shows that about $64 \%$ of any deviation between the actual value of the log of exports and the equilibrium value of the log of exports is corrected within a year.

\section{Balance-of-Payments Constrained Economic Growth Rate}

Table 3 reports growth rates and the income elasticity of demand for imports in Pakistan in 1980-2017. Using this data and based on Eq. 2, BOP-constrained growth in Pakistan was estimated to be 3.77\% per year, below Pakistan's actual average growth rate (4.89\%) for that period (Figure 2). 
Table 3: Calculation of Balance-of-Payments Equilibrium Growth Rate, 1980-2017

\begin{tabular}{|c|c|c|}
\hline Variable & Definition & Value (\%, period average) \\
\hline$\pi$ & income elasticity of demand for imports & 0.79 \\
\hline$\theta_{x}$ & share of export in foreign currency receipts & 0.75 \\
\hline$\varepsilon$ & major trading partners' income elasticity of demand for exports & 1.04 \\
\hline$z$ & major trading partners' incomes, each weighted by its export share, & 4.75 \\
\hline Exports $/ \pi$ & & 4.65 \\
\hline$\theta_{R}$ & share of remittances in foreign currency receipts & 0.25 \\
\hline$r-p_{x}$ & $\begin{array}{l}\text { growth of real remittances (growth rate of remittances - growth of export } \\
\text { price index) }\end{array}$ & 7.84 \\
\hline Remittances $/ \pi$ & & 2.45 \\
\hline$\left(p_{X}-p_{M}\right)$ & growth of terms of trade & -2.66 \\
\hline Terms of trade $/ \pi$ & & -3.33 \\
\hline$y_{B P}^{\text {augmented }}$ & BOP equilibrium growth rate & 3.77 \\
\hline
\end{tabular}

Figure 2: Economic Growth Rate and Balance-of-Payments Constraint, 1980-2017

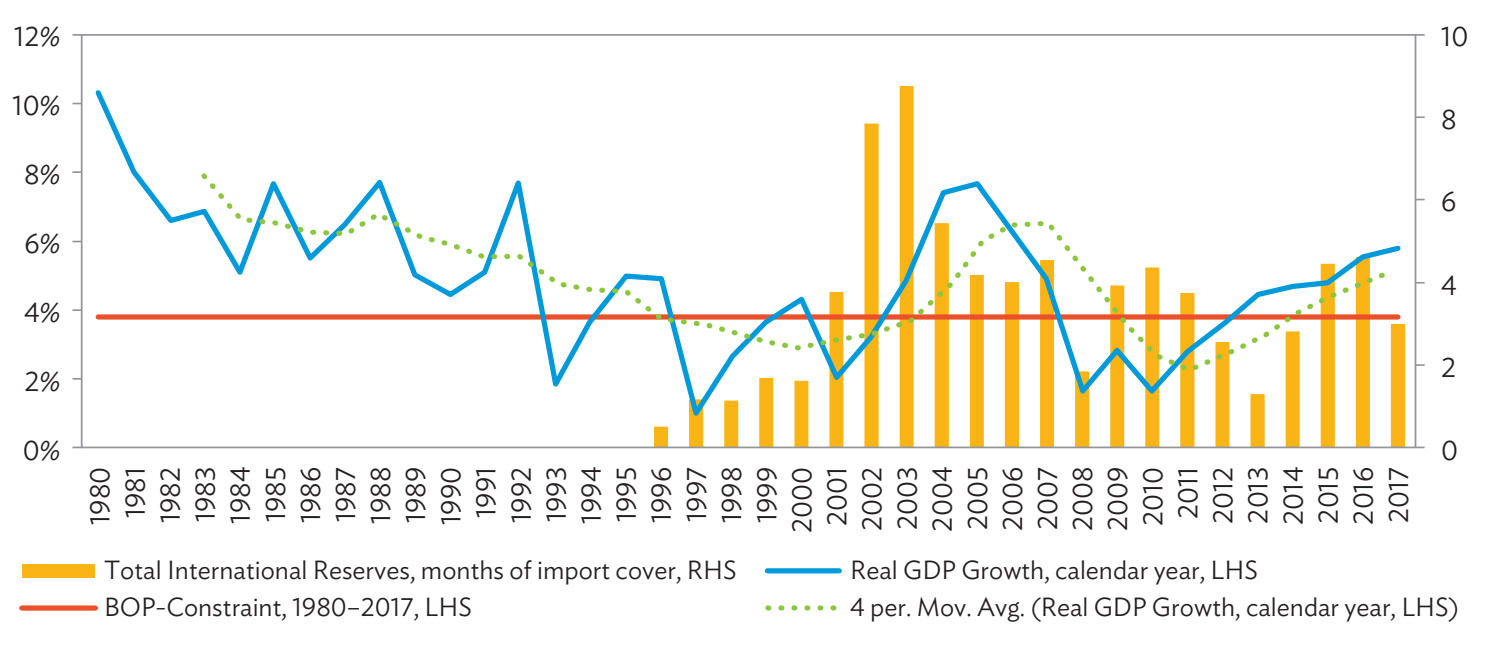

$\mathrm{BOP}=$ balance-of-payments, GDP = gross domestic product, $\mathrm{LHS}=$ left-hand side, RHS = right-hand side.

Source: Authors' calculations, State Bank of Pakistan, World Bank. 


\section{POLICY RECOMMENDATIONS}

For Pakistan's economy to grow sustainably by more than 3.8\% per year, structural reforms are required to improve export performance. This requires an upgrade in Pakistan's international specialization profile. Pakistan's industry needs to diversify and help reduce the economy's dependence on imports. A more diversified economy results in more diverse exports, and this is required to acquire the wider set of productive capabilities that is needed to export goods with a higher level of sophistication. Numerous studies have been conducted and programs implemented to help revive exports in Pakistan. ${ }^{24}$

The first steps toward export diversification could be to (i) identify the causes of lost export value in important industries (glass and stone, mineral products, plastics, and chemicals); (ii) explore options for moving into new export products that require productive capabilities similar to those used for existing Pakistani exports, but have a higher level of sophistication within the product space; (iii) generate a conducive environment for exports (terms of trade, export insurance, export promotion, and trade agreements); (iv) prepare a strategy for the garment industry, including a competitiveness assessment of current products; ( $v$ ) improve the capacities of the agencies overseeing national standards, accreditation, and certification of international standards; (vi) establish a national single window for exporters; and (vii) improve the availability of trade finance.

To implement these steps, it is required that policy design, coordination, and implementation facilitate private sector attempts to acquire capabilities in latent and more sophisticated products, as well as encourage meaningful strategies to develop new capabilities in distant products. Three policy formulation avenues were pursued: (i) pilot dialogues for structural transformation between public and private stakeholders, to demonstrate how to identify missing product-specific public inputs and the necessary private sector efforts that is required for export diversification into new products; (ii) adoption of practices that could support increases in productivity instead of subsidizing profits; and (iii) an effective textile policy to help increase sophistication and specialization (e.g., on high thread count cotton products). These steps would require a high degree of coordination among line ministries and relevant agencies.

The composition of imports contributes to the BOP constraint. Around $40 \%$ of electricity production in Pakistan is oil-based, and 25\% is gas-based. Direct and indirect subsidies for the energy sector are incentivizing oil consumption, thus driving imports. ${ }^{25}$ Investments in the country's power-generation capacity, partly under the China-Pakistan Economic Corridor,has the potential to diversify the energy mix, moving the country away from a dependence on oil-based energy supplies; this could lower dependence on energy imports, since domestic coal reserves would be used for power generation. ${ }^{26}$

As a result of these investments, the IMF predicts a diversification of Pakistan's energy mix between 2016 and 2024, with hydropower shifting from 36\% to 40\%, natural gas from $28 \%$ to $22 \%$, furnace oil from $30 \%$ to $8 \%$, coal from $0 \%$ to $18 \%$, solar and wind power from $4 \%$ to $3 \%$, and nuclear energy from $3 \%$ to $9 \% .{ }^{27}$ Accelerating energy sector reforms to reduce and rationalize subsidies for oil-based generation,

\footnotetext{
${ }^{24}$ For an example of a study, see ADB. 2010. Pakistan: Competitiveness and Structural Transformation in Pakistan. Manila. For an example of a program, see ADB. 2015. Completion Report: Pakistan; Accelerating Economic Transformation Program. Manila.

25 Fuel imports have been further subsidized through exchange rate overvaluation.

${ }^{26}$ IMF. 2017. Pakistan: Selected Issues. IMF Country Reports. No. 17/213. Washington, DC.

27 The earlier percentages do not add up to $100 \%$ due to rounding.
} 
incentivize renewable energy generation, and reduce losses are important structural reforms to alleviate the effects of energy imports on the BOP.

The high proportion of remittances coming from Middle Eastern oil-exporting countries, specifically from workers in the highly cyclical construction industry, results in remittance receipt fluctuations in relation to oil prices. On the upside, this provides a (delayed) hedge against fluctuations in the oil price, Pakistan's main import. A more diversified distribution of migrant worker destination countries would help decouple remittances from oil price developments.

\section{CONCLUSIONS}

This paper estimates a long-term structural BOP-constrained GDP growth rate of 3.77\% for the period 1980-2017. At 4.89\%, the average GDP growth rate for that period is higher than the BOP equilibrium GDP growth rate. Periods of GDP growth rates that are higher than the BOP-constrained growth rate tend to result in foreign exchange reserve depletion, followed by periods of fiscal and monetary policy-led suppressed growth.

Stagnating value of exports since 2012 and slowing remittance growth since 2014 are likely further shifting the BOP equilibrium growth rate downwards. While Felipe et al. estimates a higher BOP equilibrium growth rate than the estimates in this paper, the calculations are based on figures that include 2008-2017.28 The difference in these estimates can be explained by slowing export growth, and more disadvantageous terms of trade. Following the relaxation of the exchange rate in 2018, measures were taken in 2019 to compress demand through policy rate increases, which allowed for an adjustment of the terms of trade. These measures are likely to help recover foreign exchange reserves in the shortrun. Structurally, however, external imbalances will require consistent policy interventions for promoting export growth and reducing Pakistan's import elasticity of income.

The long-term estimate of income elasticity of imports is at 0.8, indicating that a 1.0\% GDP growth will lead to a $0.8 \%$ increase in imports. The short-term import elasticity on income seems to increase with higher GDP growth. Other papers have estimated a wide range of elasticities; for instance, the range was 0.5-3.2 for studies published between 2001 and 2010. ${ }^{29}$ Figure 1 suggests that within the range of 3.0\%-5.0\% GDP growth, the import elasticity of GDP growth seems to be around 1.0. When GDP growth is either lower or higher than that range, import growth appears to react disproportionately, almost to a level of an exponential relationship. This observation would need to be further tested in future research, with multi-country data or through a time-varying estimation approach. If import elasticity would again show an increase when GDP growth rates increase, structural reforms to change this correlation would be necessary to ensure Pakistan's sustainable development.

Since end-2017, the government implemented a number of economic reforms to address the BOP crisis, including regulatory measures, reduced imports, increased interest rates, and depreciation of the exchange rate to the US dollar by almost 33\%. In July 2019, Pakistan entered an IMF extended fund facility, with the aim to address low foreign exchange reserves, fiscal and external imbalances, stimulate growth, and reduce inflation. The current account deficit (4.8\%) of GDP in FY2019 continues to keep the foreign exchange reserves under pressure. Workers' remittances, after stagnating for three years, grew by

\footnotetext{
${ }^{28}$ Footnote 2.

${ }^{29}$ Footnotes 10-12.
} 
9.7\%, lending support to the current account. Nonetheless, in spite of significant currency depreciation, merchandise exports declined by 2.2\%, between FY2018 and FY2019. On average, over the last decade, Pakistan has lost global market share by $1.45 \%$ per annum, with foreign exchange reserves further declining from $\$ 9.8$ billion at the end of FY2018 to $\$ 7.3$ billion at the end of FY2019, only enough to finance about 1.4 months of imports. Hence, improving Pakistan's export performance remains the most relevant long-term structural challenge to alleviate the balance-of-payments constraint to sustained economic growth. 


\section{APPENDIX 1: PESARAN, SHIN, AND SMITH (2001) BOUNDS TEST}

\section{ARDL $(1,1,0)$ Model for Imports Demand Equation}

The autoregressive distributed lag (ARDL) model allows application of the Bounds test, the null hypothesis of which is that there is no long-run relationship between the variables, in this case between imports, gross domestic product (GDP), and relative effective exhange rate (REER). The F-statistic value (5.698) is evidently greater than the I(1) critical value bound at $5 \%$ significative level. The null hypothesis that there is no equilibrating relationship can be rejected. Moreover, since the null was rejected and since a constant or trend in the cointegrating relationship was not included, the T-Bounds test critical values can be used. The absolute value of t-statistic is 3.590 and is greater than the absolute value of either the $\mathrm{I}(0)$ or I(1) t-bound at 5\%. It indicates that the T-Bounds test null hypothesis should be rejected and that in conclusion, the cointegrating relationship is either of the usual kind or is valid but degenerate.

Table A1.1: ARDL $(1,1,0)$ Model for Imports Demand Equation

\begin{tabular}{|c|c|c|c|c|c|c|}
\hline \multicolumn{7}{|c|}{$\begin{array}{l}\text { HO: No level relationship } \\
\text { F-statistic: } 5.698 \\
\text { t-statistic: }-3.590 \\
\text { k=2 }\end{array}$} \\
\hline & \multicolumn{2}{|c|}{$10 \%$} & \multicolumn{2}{|c|}{$5 \%$} & \multicolumn{2}{|c|}{$1 \%$} \\
\hline & $\mathrm{I}(0)$ & $\mathrm{I}(1)$ & $\mathrm{I}(0)$ & $\mathrm{I}(1)$ & $\mathrm{I}(0)$ & $\mathrm{I}(1)$ \\
\hline F-test & 3.17 & 4.14 & 3.79 & 4.85 & 5.15 & 6.36 \\
\hline t-test & -2.57 & -3.21 & -2.86 & -3.53 & -3.43 & -4.10 \\
\hline
\end{tabular}

\section{ARDL $(1,5,0)$ Model for Exports Demand Equation}

The F-statistic value (4.237) and the t-statistic absolute value ( -3.315$)$ are both greater than the I(1) critical value bound at $10 \%$ significative level. The null hypothesis that there is no equilibrating relationship can be rejected.

Table A1.2: ARDL $(1,5,0)$ Model for Exports Demand Equation

\begin{tabular}{|c|c|c|c|c|c|c|}
\hline \multicolumn{7}{|c|}{$\begin{array}{l}\text { HO: No level relati } \\
\text { F-statistic: } 4.237 \\
\text { t-statistic: }-3.315 \\
\mathrm{k}=2\end{array}$} \\
\hline & \multicolumn{2}{|c|}{$10 \%$} & \multicolumn{2}{|c|}{$5 \%$} & \multicolumn{2}{|c|}{$1 \%$} \\
\hline & $\mathrm{I}(0)$ & $\mathrm{I}(1)$ & $\mathrm{I}(0)$ & $\mathrm{I}(1)$ & $I(0)$ & $\mathrm{I}(1)$ \\
\hline F-test & 3.17 & 4.14 & 3.79 & 4.85 & 5.15 & 6.36 \\
\hline $\mathrm{t}$-test & -2.57 & -3.21 & -2.86 & -3.53 & -3.43 & -4.10 \\
\hline
\end{tabular}




\section{APPENDIX 2: DIAGNOSTIC TESTS FOR IMPORT AND EXPORT DEMAND EQUATIONS}

Table A2.1: Imports Demand Regression Model ARDL (1,1,0): Breusch-Pagan/Cook-Weisberg Test for Heteroskedasticity

\begin{tabular}{ll}
\hline HO: Constant variance & \\
Variables: Fitted values of Log(Imports) & \\
\hline Chi2 (1) & 0.59 \\
Prob > chi2 & 0.4410
\end{tabular}

Table A2.2: Imports Demand Regression Model ARDL (1,1,0): Breusch-Godfrey LM Test for Autocorrelation

\begin{tabular}{lccc}
\hline $\begin{array}{l}\text { Breusch-Godfrey LM test for autocorrelation } \\
\text { HO: No serial correlation }\end{array}$ & & \\
\hline Lags $(\mathrm{p})$ & $\mathrm{F}$ & $\mathrm{df}$ & Prob > F \\
\hline 1 & 2.712 & $(1,31)$ & 0.1097 \\
2 & 1.412 & $(2,30)$ & 0.2594 \\
3 & 1.363 & $(3,29)$ & 0.2736 \\
4 & 1.317 & $(4,28)$ & 0.2878 \\
\hline
\end{tabular}

Table A2.3: Imports Demand Regression Model ARDL (1,1,0): Cumulative Sum Test for Parameter Stability

Sample: 1981-2017

Number of observations $=37$

HO: No structural break

\begin{tabular}{lcccc}
\hline Statistic & Test Statistic & 1\% Critical Value & 5\% Critical value & 10\% Critical Value \\
\hline Recursive & 0.8510 & 1.1430 & 0.9479 & 0.850 \\
\hline
\end{tabular}

Table A2.4: Imports Demand Regression Model ARDL (1,1,0): Wald Test for a Structural Break (Structural Break in 2001)

\begin{tabular}{ll}
\hline Number of observations $=37$ & \\
Sample: $1981-2017$ & \\
Break date: 2001 & \\
HO: No structural break & 2.6054 \\
\hline Chi2 & 0.7605 \\
Prob > chi2 & \\
\hline
\end{tabular}

Table A2.5: Cumulative Sum Test for Parameter Stability

Sample: 1986-2017

Number of observations $=32$

HO: No structural break

\begin{tabular}{lcccc}
\hline Statistic & Test Statistic & 1\% Critical Value & 5\% Critical Value & 10\% Critical Value \\
\hline Recursive & 0.8418 & 1.1430 & 0.9479 & 0.850 \\
\hline
\end{tabular}


Table A2.6: Exports Demand Regression Model ARDL (2,6,0): Breusch-Pagan/Cook-Weisberg Test for Heteroskedasticity

\begin{tabular}{ll} 
Breusch-Pagan/Cook-Weisberg test for heteroskedasticity & \\
HO: Constant variance & \\
Variables: Fitted values of Log(Exports) & 0.46 \\
\hline Chi2 (1) & 0.4994 \\
Prob > chi2 & 0.46
\end{tabular}

Table A2.7: Exports Demand Regression Model ARDL $(2,6,0)$ : Breusch-Godfrey Lagrange Multiplier Test for Autocorrelation

\begin{tabular}{lccc}
\hline HO: No serial correlation & & & \\
\hline Lags $(\mathbf{p})$ & $\mathbf{F}$ & $\mathbf{d f}$ & Prob > F \\
\hline 1 & 0.024 & $(1,20)$ & 0.8783 \\
2 & 0.055 & $(2,19)$ & 0.9470 \\
3 & 0.058 & $(3,18)$ & 0.9813 \\
4 & 0.579 & $(4,17)$ & 0.6816 \\
\hline
\end{tabular}

Table A2.8: Augmented Dickey-Fuller Test for Unit Root

\begin{tabular}{|c|c|c|c|c|}
\hline \multicolumn{5}{|c|}{$\begin{array}{l}\text { Number of observations = } 36 \\
\text { Interpolated Dickey-Fuller }\end{array}$} \\
\hline & Test Statistic Z(t) & $1 \%$ Critical Value & $5 \%$ Critical Value & $10 \%$ Critical Value \\
\hline $\begin{array}{l}\log (\text { Imports }) \\
\mathrm{Z}(\mathrm{t})\end{array}$ & -0.737 & $\begin{array}{l}0.8369 \\
-3.675\end{array}$ & -2.969 & -2.617 \\
\hline \multicolumn{5}{|c|}{ MacKinnon approximate $p$-value for $Z(t)=0.8369$} \\
\hline $\log (G D P)$ & -1.101 & & 0.7146 & \\
\hline $\log (R E E R)$ & -3.480 & & 0.0085 & \\
\hline Log(Exports) & -1.887 & & 0.3383 & \\
\hline \multicolumn{5}{|c|}{$\begin{array}{l}\text { Number of observations = } 36 \\
\text { Interpolated Dickey-Fuller }\end{array}$} \\
\hline & Test Statistic & $1 \%$ Critical Value & $5 \%$ Critical Value & $10 \%$ Critical Value \\
\hline $\mathrm{Z}(\mathrm{t})$ & -1.101 & -3.675 & -2.969 & -2.617 \\
\hline \multicolumn{5}{|c|}{ MacKinnon approximate $p$-value for $Z(t)=0.7146$} \\
\hline \multicolumn{5}{|c|}{$\begin{array}{l}\text { Number of observations = } 37 \\
\text { Interpolated Dickey-Fuller }\end{array}$} \\
\hline & Test Statistic & $1 \%$ Critical Value & $5 \%$ Critical Value & $10 \%$ Critical Value \\
\hline$Z(t)$ & -3.480 & -3.668 & -2.966 & -2.616 \\
\hline \multicolumn{5}{|c|}{ MacKinnon approximate $p$-value for $Z(t)=0.0085$} \\
\hline \multicolumn{5}{|c|}{$\begin{array}{l}\text { Number of observations = } 36 \\
\text { Interpolated Dickey-Fuller }\end{array}$} \\
\hline & Test Statistic & $1 \%$ Critical Value & $5 \%$ Critical Value & $10 \%$ Critical Value \\
\hline$Z(t)$ & -1.887 & -3.675 & -2.969 & -2.617 \\
\hline MacKinnon ap & alue for $Z(t)=0.33$ & & & \\
\hline
\end{tabular}




\section{Why Pakistan's Economic Growth Continues to Be Balance-of-Payments Constrained}

This paper analyzes Pakistan's recurring balance-of-payments crisis. Based on 1980-2017 data and using long-term estimates of import and export income elasticities, the balance-of-payments constrained growth rate is estimated at $3.8 \%$. The result is lower than previous estimates of balance-of-payments constrained growth in the literature, indicating that lower export performance weighed more on gross domestic product growth in the recent period. In this paper, structural reforms are recommended to improve Pakistan's export performance.

\section{About the Asian Development Bank}

ADB is committed to achieving a prosperous, inclusive, resilient, and sustainable Asia and the Pacific, while sustaining its efforts to eradicate extreme poverty. Established in 1966, it is owned by 68 members -49 from the region. Its main instruments for helping its developing member countries are policy dialogue, loans, equity investments, guarantees, grants, and technical assistance. 